E-ISSN : $2620-5858$

\title{
Hukum Kepemimpinan Wanita: Perspektif Ulama
}

\author{
Muhajir, Fakhrurrazi \\ IAIN Langsa \\ (syechmuhajir@yahoo.com)(frazilgs@yahoo.com)
}

\begin{abstract}
The purpose of this study was to determine the law of female leadership according to the perspective of the Langsa City Ulama in the local elections for the mayor and to identify the factors that influence the different views of the Langsa City Ulama about female leadership in the Langsa City. The method used in this study is a qualitative descriptive research method that produces data in the form of written and spoken words from the subject under study. The main target of this research is the ulama of Langsa city. Data collection techniques are by observation, in-depth interviews and documentation. The data validity used is data triangulation technique. Data analysis includes 4 things, namely data collection, data reduction, data presentation, and concluding. The result of this research is that the ulama of Langsa city show that women can be leaders in the public sector, but the concept of understanding ideal leadership in Islamic teachings that they understand places men as the top priority to become leaders. Women are deemed to be allowed to become leaders if there are no men who can hold the position or the woman has more talent or expertise than the existing men.
\end{abstract}

Keywords: Law, Leadership, Women, Ulama

Abstrak: Tujuan dalam penelitian ini adalah untuk menjelaskan hukum kepemimpinan wanita menurut perspektif Ulama Kota Langsa dalam pilkada Walikota dan mengidentifikasi faktor yang mempengaruhi terjadi perbedaan pandangan ulama kota langsa tentang kepemimpinan wanita di kota langsa. Metode yang digunakan dalam penelitian ini adalah metode penelitian deskriptif kualitatif yang menghasilkan data berupa kata-kata tertulis maupun lisan dari subjek yang diteliti. Sasaran utama dalam penelitian ini adalah ulama kota Langsa. Teknik pengumpulan data adalah dengan observasi, wawancara mendalam dan dokumentasi. Validitas data yang digunakan adalah teknik trianglusi data. Analisis data mencakup 4 hal yaitu pengumpulan data, reduksi data, penyajian data, dan penarikan simpulan. Hasil dalam penelitian ini adalah ulama kota Langsa menunjukkan bahwa perempuan boleh menjadi pemimpin disektor publik, tetapi konsep akan pemahaman kepemimpinan ideal dalam ajaran Islam yang mereka pahami menempatkan laki-laki sebagai prioritas utama untuk menjadi pemimpin. Perempuan dianggap boleh untuk menjadi pemimpin jika tidak ada laki-laki yang mampu mengemban posisi tersebut atau perempuan itu memiliki bakat atau keahlian yang lebih dari pada laki-laki yang ada.

Kata Kunci: Hukum, Kepemimpinan, Wanita, Ulama

\section{PENDAHULUAN}

Kedudukan wanita dipandang rendah sebelum Islam datang, mereka tidak berhak mendapat harta warisan. Harta hanya hak monopoli kaum pria saja. Setelah Islam datang, wanita merasa mendapat angin segar. Mereka diperlakukan selayaknya manusia pada umumnya, tidak ada pilih kasih antara pria dan wanita. Pada zaman sekarang ini, para wanita ikut serta mengambil bagian hampir pada semua lapangan kegiatan atau pekerjaan termasuk dalam pemilihan kepala daerah. Di Indonesia, ada wanita yang menjadi Menteri, Pemimpin Perusahaan, Angkatan Bersenjata, Anggota Majelis Permusyawaratan Rakyat, Pegawai Negeri Sipil, Kepala Sekolah dan menjadi buruh serta ibu rumah tangga yang saat ini dianggap sebagai lapisan bawah (Muhammad Ali Ash-Shalabi, 2012: 64).

Para wanita telah ikut secara aktif dalam membangun rumah tangga dan negara. Malahan ada yang kita lihat agak berlebihan, karena wanita lebih banyak

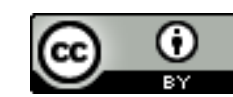

This work is licensed under a Creative Commons Attribution 4.0 International License 


\section{VOLUME 13 NOMOR 2 TAHUN 2020}

P-ISSN : 1979-9357

E-ISSN : $2620-5858$

memegang peranan dalam membiayai rumah tangga. Pada sebahagian daerah, ada banyak wanita yang mencari nafkah, meninggalkan kampung halaman untuk pergi keluar kota bahkan keluar negeri untuk bekerja, sedangkan suami tinggal dirumah, mengurus anak-anak dan sawah (Hasan Ali, 2003: 73).

Semua itu dilakukan tentu dilakukan karena ada berbagai macam sebab atau alasan. Para wanita bekerja mungkin terdorong untuk berbakti kepada keluarga, masyarakat dan negara. Bisa saja karena keadaan memaksa mereka untuk itu karena biaya hidup berumah tangga tidak tertanggulangi, karena pendapatan suami tidak mencukupi, dan lain sebagainya. Boleh jadi juga, karena di telinga mereka terngiang-ngiang suara persamaan hak dan derajat antara pria dan wanita. Dalam Al-Qur'an Allah menjelaskan mengenai kedudukan wanita, di antaranya Allah berfirman surat At-Taubah Ayat 71:

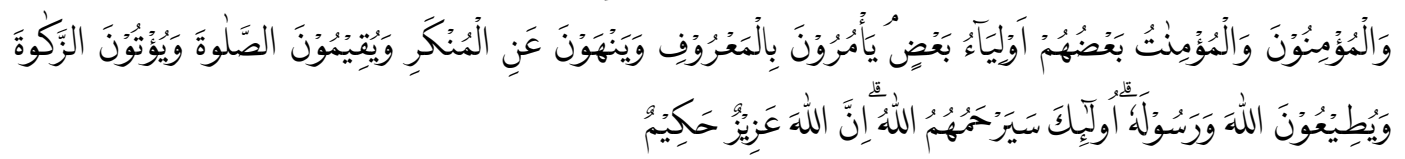

Artinya "...dan orang-orang yang beriman, lelaki dan perempuan, sebahagian mereka (adalah) menjadi penolong bagi sebahagian yang lain. mereka menyuruh (mengerjakan) yang ma'ruf, mencegah dari yang munkar, mendirikan shalat, menunaikan zakat dan mereka taat pada Allah dan Rasul-Nya. mereka itu akan diberi rahmat oleh Allah; Sesungguhnya Allah Maha Perkasa lagi Maha Bijaksana"

Dari ayat di atas dapat dipahami bahwa pria dan wanita saling tolong menolong, terutama dalam satu rumah tangga dan mempunyai tugas dan kewajiban yang sama untuk menjalankan amar ma'ruf dan nahi munkar.

Allah juga berfirman dalam QS. An-Nisaa' 32:

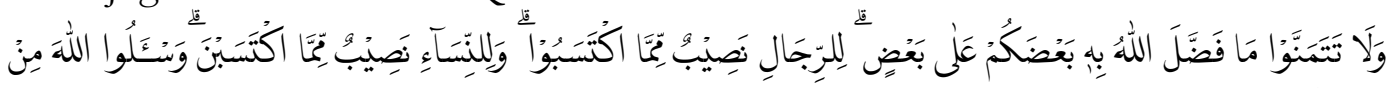

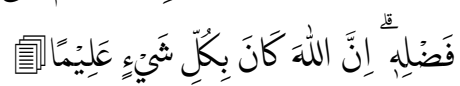

"Dan janganlah kamu iri hati terhadap apa yang dikaruniakan Allah kepada sebagian kamu lebih banyak dari sebagia yang lain. (Karena) bagi orang laki-laki ada bagian daripada apa yang mereka usahakan, dan bagi para wanita (pun) ada bagian dari apa yang mereka usahakan..." (An-Nisaa: 32).

Ayat ini pun cukup jelas memberi gambaran, bahwa tidak ada diskriminasi bagi wanita, tidak ada alasan untuk merendahkan derajat kaum wanita. Semuanya bergantung kepada amalan masing-masing. Wanita mempunyai hak dari hasil usahanya sebagaimaa pria, disamping juga mempunyai kewajiban. Akan tetapi dalam hal tertentu, kedudukan wanita tidak harus sama benar dengan kaum pria. Bukan karena kurang penghargaan, tetapi karena kodrat wanita yang menghendaki demikian. Sebagaimana firman Allah SWT Surat Annisa' ayat 34:

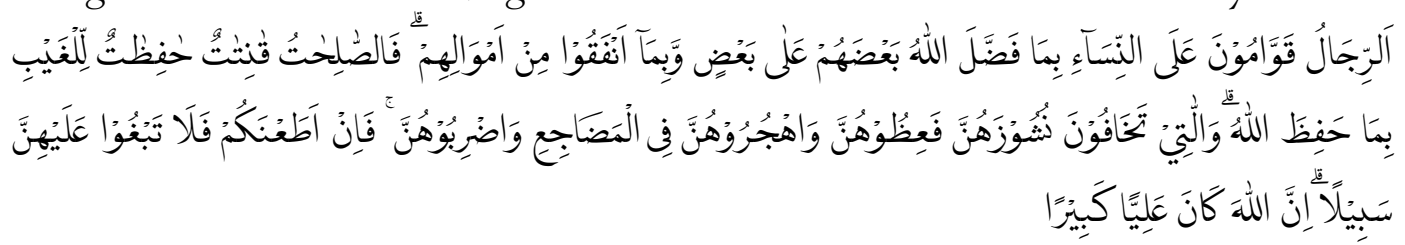


VOLUME 13 NOMOR 2 TAHUN 2020

P-ISSN : 1979-9357

E-ISSN : 2620-5858

Artinya: "Kaum laki-laki itu adalah pemimpin bagi kaum wanita, oleh karena Allah telah melebihkan sebagian mereka (laki-laki) atas sebagian yang lain (wanita) dan karena mereka (laki-laki) telah menafkahkan dari harta mereka..." (An-Nisa: 34)

Para mufasir menyatakan bahwa qawwam berarti pemimpin, pelindung, penanggung jawab, pendidik dan pengatur. Selanjutnya, mereka mengatakan bahwa kelebihan yang dimiliki laki-laki atas perempuan adalah karena keunggulan akal dan fisiknya. Ath-Thabathaba'i berpendapat bahwa kelebihan laki-laki atas perempuan adalah karena ia memiliki kemampuan berpikir, yang karena itu melahirkan keberanian, kekuatan dan kemampuan mengatasi berbagai kesulitan. Sementara perempuan lebih sensitif dan emosional (Departemen Agama RI, Alquran Terjemahan, 2014: 81). Sebelum memasuki pembahasan tentang kepemimpinan wanita, perlu kita ketahui tentang syarat-syarat menjadi seorang pemimpin.

Syarat sah seseorang menjadi seorang pemimpin sebagai kepala daerah atau negara dalam pandangan Islam adalah sebagai berikut:

1. Mempunyai syarat kepemimpinan secara sempurna, yaitu: Islam, merdeka (bukan budak), lelaki, baligh dan berakal sehat.

2. Mengerjakan agama secara baik, benar, berakhlak mulia, memegang amanah, bersih dan menghindari perbuatan yang dilarang oleh agama, dan lain sebagainya.

3. Memiliki cukup ilmu yang bisa mengantarkannya kepada suatu ijtihad, jika terjadi permasalahan yang mendesak sesuai dengan syariat terutama di dalam urusan politik Negara.

4. Sempurna dan kuatnya pemeliharaan di dalam permasalahan politik, strategi peperangan dan administrasi demi kepentingan rakyat.

5. Berkepribadian tegar dan bersifat tegas, pemberani dalam mengambil keputusan, demi menjaga keselamatan bangsa dan menolak penjajahan dalam segala bidang.

6. Kesempurnaan jiwa raga, sehat jasmani dan panca indera, sehingga tidak memerlukan perantara dalam memahami situasi.

7. Dari keturunan dan keluarga yang baik (Muhammad Husein, 2001:23).

Ada tiga pandangan tentang kepemimpinan perempuan dalam fiqh Islam, yaitu:

1. Wanita tidak mempunyai hak sama sekali dalam berpolitik. Di antara dalil yang dipakai untuk menguatkan pendapat mereka adalah adanya ketentuan laki-laki adalah pemimpin (An-Nisa 32 dan 34, Al-Baqarah: 228), hadis Abu Bakrah, ketika Rasulullah mengetahui Kaum Parsi dipimpin oleh seorang wanita, Rasulullah bersabda: "Tidak akan bahagia suatu kaum yang menyerahkan urusannya kepada wanita." (HR Bukhari Muslim).

2. Sebagian besar ulama klasik dan kontemporer, memandang wanita memiliki hak berpolitik yang sama seperti laki-laki kecuali memegang pucuk pemerintahan (presiden), dengan beralasan bahwa laki-laki dan perempuan mempunyai hak dan kewajiban yang sama dalam Islam (Al-Baqarah:228, Al- 
VOLUME 13 NOMOR 2 TAHUN 2020

P-ISSN : 1979-9357

E-ISSN : $2620-5858$

Hujurat:13, Al-Taubah: 71 dan Al-Nur: 30-31). Alasan pendapat yang kedua bahwasanya wanita untuk berpartisipasi dalam wilayah politik, seperti bukti sejarah tentang suksesnya Ratu Bilqis yang memerintahkan Saba (Al-Naml : 32-34). Rasulullah juga mengakui suaka politik dari kaum wanita, seperti Ummu Hani dalam peristiwa Fath Mekkah, Rasulullah juga menerima bai'at kaum wanita. Juga penyebaran dakwah Islam dengan periwayatan hadis yang dilakukan juga oleh kaum Muslimah seperti Aisyah ra.

3. Pendapat ketiga memandang wanita berhak berpolitik seperti laki-laki termasuk memegang pucuk pemerintahan. Kelompok yang sebagian besar ulama kontemporer ini mengintepretasikan Hadis Abu Bakrah khusus ditujukan untuk Kaum Persia yang saat itu dipimpin oleh seorang wanita, bukan dipukul rata untuk semua kaum. Juga mengambil dalil dari kisah sukses Ratu Bilqis yang diceritakan dalam Al-Qur'an (An Naml : 32-34), serta suksesnya pemimpin wanita seperti Margareth Teacher, Indira Gandhi, bahkan kerajaan Aceh pernah dipimpin oleh seorang wanita.

Secara kenyataan dan realitas sekarang ini memperlihatkan bahwa pandangan mengenai kehebatan laki-laki dan kelemahan wanita dari sisi intelektual dan profesi. Kehebatan intelektual dan profesi adalah dua hal yang menjadi syarat bagi kepemimpinan. Dengan syarat seperti ini, terbuka kesempatan yang luas bagi perempuan untuk menduduki posisi-posisi kepemimpinan publik, termasuk menjadi kepala daerah.

\section{METODE PENELITIAN}

Penelitian ini merupakan jenis penelitian lapangan (Field Research) yang bersifat kualitatif dan penelitian kepustakaan (Library Research) (Lexy J. Maleong, 2007: 13; Winarno Surachman, 1985:65; Whitney (1960);Mohd. Nasir, 1988:85). Penelitian ini dilakukan di Kota langsa, dengan subjek penelitian Ulama Kota Langsa dan pimpinan pesantren, dayah, Imam mesjid dan ulama akademik (Perguruan tinggi), selama kurang lebih 4 bulan (Maret-Juli). Subyek penelitian adalah sumber-sumber yang memungkinkan untuk memperoleh keterangan penelitian atau data. Adapun yang dijadikan subyek dalam penelitian ini adalah ulama sebagai komponen masyarakat yang ada di Kota Langsa yang dipilih secara acak. Berdasarkan jumlah informan yang dikumpulkan dalam penelitian sebanyak 10 orang ulama kota Langsa.

\section{HASIL DAN PEMBAHASAN PENELITIAN}

\section{Konsep Kepemimpinan Dalam Pandangan Islam}

Pada prinsipnya kepemimpinan menurut al-Qur'an adalah tugas harus dilaksanakan oleh orang yang 'palang cocok'. Orang itu adalah orang yang paling cocok berdasarkan kualifikasi atau karakteristik yang dibutuhkan untuk menunaikan tugas itu, baik secara biologis, psikologis, pendidikan, keuangan, pengalaman, dan sebagainya.

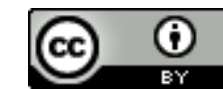

This work is licensed under a Creative Commons Attribution 4.0 International License 
VOLUME 13 NOMOR 2 TAHUN 2020

P-ISSN : 1979-9357

E-ISSN : 2620-5858

Sistem patriarkal bangsa arab memberikan beberapa keunggulan bagi lakilaki. Sehingga dengan memiliki hak istimewa di depan publik, pengalaman, dan keunggulan lainnya, laki-laki menjadi yang paling cocok dan ahirnya menjadikan mereka yang paling sesuai untuk memegang kepemimpinan. Namun menurut alQur'an keunggulan ini tidak terbatas untuk laki-laki. Asalkan wanita mempunyai motivasi, dan peluang, serta kemampuan untuk menjadi yang paling 'cocok', meraka pun pasti bisa. Bahkan dalam konteks negeri Arab yang patriarkal, alQur'an memberikan contoh seorang pemimpin wanita, yakni Bilqis (Amina Wadud, 2001:156)

Setidaknya ada dua pendapat mengenai kepemimpinan wanita dalam Islam. Pendapat pertama mengatakan bahwa wanita dalam Islam tidak dapat menjadi pemimpin dalam kehidupan publik, sedangkan pendapat kedua menyatakan sebaliknya, bahwa sejalan dengan konsep kemitra sejajaran yang diajarkan Islam, maka wanita boleh menjadi pemimpin dalam masyarakat atau dalam kehidupan publik. Pendapat pertama bersifat konservatif, sedangkan pendapat yang kedua bersifat liberal.

\section{Kepemimpinan Wanita}

Menurut Abdullah dalam Astuti (2008:120) kehidupan perempuan merupakan realitas yang kompleks dapat dilihat dari dua aspek yaitu, pertama, bahwa realita situ tersusun dari unsure yang begitu banyak yaitu agama, budaya, ekonomi, politik, atau lingkungan fisik suatu tempat. Yang kedua, bahwa realitas hidup perempuan tersusun dari unsur yang berlapis, yang lapisannya itu tidak lebih suatum isteri yang perlu diungkapkan dengan membuka lapis demi lapis tersebut. Wacana tentang kesetaraan laki-laki dan perempuan merupakan fenomena global yang merasuk melintasi batas-batas wilayah,agama, kebudayaan dan tradisi. Masalah relasi laki-laki dan perempuan jika dikaitkan dengan Islam masih menjadi masalah yang kontraversioanal. Persoalan ini tidak semata-mata bisa disekati dengan pemaparan final doktrin-doktrin keagamaan, melainkan harus memperhitungkan aspek - aspek sosial, budaya, politik dan lainnya yang meliputi doktrin-doktrin tersebut (Astuti,2008:120).

Kedudukan perempuan dalam perspektif Islam dapat dikaji secara tekstual dan kontekstual. Dari segi tekstual kita mempelajari dan memahami kedudukan perempuan dalam perspektif menurut ajaran-ajaran normatif sebagaimana tertulis dalam Al-Qur'an dan pandangan-pandangan buku dari para ulama ahli fikih yang telah memberikan penafsiran tertentu terhadap ajaranajaran normatif yang difirmankan Allah SWT. Sedangkan secara kontekstual, para ulama tersebut mengkaji latar belakang turunnya ayat-ayat Al-Qur'an, serta keadaan sosial politik dan budaya pada saat hidup dan melakukan penafsiran, sehingga yang lebih penting adalah keyakinan dari para ulama itu sendiri (Astuti,2008:124).

Berdasarkan pembahasan di atas menunjukkan bahwa dalam pandangan ulama kota langsa, sebenarnya perempuan mempunyai hak dan kesempatan berkarir yang sama dalam menjalankan tugasnya sebagai wanita karir ketika dia memilih untuk bekerja sebagai pemimpin di sektor publik atau di pemerintahan,

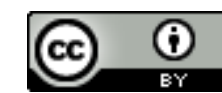

This work is licensed under a Creative Commons Attribution 4.0 International License 
VOLUME 13 NOMOR 2 TAHUN 2020

P-ISSN : 1979-9357

E-ISSN : $2620-5858$

namun ada pembatasan yang diberlakukan, yaitu dengan tidak melalaikan fungsi dan kedudukannya sebagai wanita secara alamiah. Atau lebih tepatnya sebagai wanita karir tidak boleh melupakan kodratnya sebagai perempuan, yaitu mendidik anak, mengurus keluarga dan suami.

Persepsi yang diberikan oleh ulama kota langsa menempatkan perempuan sebagai makhluk lemah yang kurang pantas menempati posisi kepemimpinan di pemerintahan. Namun wanita yang menjadi objek persepsi dengan dipersepsikan sebagai sosok yang lemah, tidak rasional, tidak tegas, pemikirannya pendek malah mangakuinya sebagai sesuatu yang memang menggambarkan mereka secara umum. Perempuan mempunyai hak yang sama dengan laki-laki untuk menjadi pemimpin asalkan dia memiliki kemampuan (ahli) dan tidak ada lagi laki-laki yang bisa memimpin, karena dalam pandangan ulama kota Langsa apapun yang diserahkan kepada yang bukan ahlinya akan hancur.

Perempuan diperbolehkan menjadi pemimpin asalkan dia mempunyai keahlian dalam memimpin, ulama mencontohkan bahwa banyak daerah yang kepemimpinannya dikuasai perempuan malah sukses, sedangkan kepemimpinan yang kuasai laki-laki malah hancur. Jadi siapa yang lebih ahli maka dialah yang pantas menjadi pemimpin, baik perempuan atau laki- laki sama saja. Perempuan jika memiliki keahlian untuk memimpin maka dia bisa Dan boleh menjadi pemimpin, tetapi yang memiliki kemampuan lebih dari pada perempuan atau setaranya, ulama kota Langsa mengatakan maka laki-laki sebaiknya diprioritaskan dalam memimpin.

Perempuan boleh menjadi pemimpin tetapi dianggap kurang tepat untuk menempati posisi tersebut karena dalam padangan santri perempuan dianggap memiliki kelemahan yang tidak sesuai dengan kriteria yang harus dimiliki seorang pemimpin. Karena dalam pandangan santri kelebihan yang dimiliki perempuan adalah relatif atau artinya laki-laki juga memiliki kelebihan tersebut, sedangkan kelebihan yang dimiliki laki-laki tidak dimiliki perempuan salah satunya adalah perangai psikologis laki-laki yang digambarkan memiliki fisik yang kuat sehingga Menjustifikasi bahwa laki-laki dapat bersikap tegas. Karena untuk menjadi pemimpin diperlukan ketegasan sebagai penentu kebijakan bagi kelompok yang dipimpinnya.

\section{KESIMPULAN}

Ulama menganggap bahwa perempuan boleh menjadi pemimpin disektor publik, tetapi konsep akan pemahaman kepemimpinan ideal dalam ajaran Islam yang mereka pahami menempatkan laki-laki sebagai prioritas utama untuk menjadi pemimpin. Perempuan dianggap boleh untuk menjadi pemimpin jika tidak ada laki-laki yang mampu mengemban posisi tersebut, atau perempuan itu memiliki bakat atau keahlian yang lebih dari pada laki-laki yang ada. Karena dalam Islam untuk menempati posisi kepemimpinan adalah mengutamakan ahli, siapa yang ahli atau memiliki kemampuan maka boleh menjadi pemimpin, namun juga dikatakan bahwa jika ada laki-laki yang setaranya maka memprioritaskan laki-laki sebagai pemimpin. Kelebihan dan kelemahan yang dimiliki perempuan bersifat relatif, artinya kelebihan yang dimiliki perempuan juga dimiliki laki-laki, 
VOLUME 13 NOMOR 2 TAHUN 2020

P-ISSN : 1979-9357

E-ISSN : $2620-5858$

dan kelemahan yang dimiliki perempuan laki-lakipun ada yang demikian. Namun perangai psikologis yang dimiliki perempuan dengan sifat keibuan mereka, menjadikan perempuan lebih mengandalkan perasaannya sehingga dianggap kurang tegas. Maka dari itu kemudian ulama menganggap bahwa laki-laki lebih diprioritaskan untuk menjadi pemimpin di pemerintahan, karena dunia publik adalah dunia yang keras dunia yang penuh debat dan posisi kepemimpinan memerlukan ketegasan orang yang memimpin dalam menentukan keputusan dengan cepat dan tepat. Kelemahan lain yang turut memengaruhi kepemimpinan wanita disektor publik bahwa kepemimpinan waniata disektor publik legitimasinya kurang diakui karena perempuan dianggap telah melanggar ketentuan agama, apalagi dengan dominasi patriarkhi dalam kehidupan masyarakat yang ada saat ini. Sehingga ketika menjadi pemimpin disektor publik perempuan tidak maksimal dalam menjalanan tugas dan kewajibannya sebagai pemimpin.

\section{DAFTAR PUSTAKA}

Astuti, (2008), Konstruksi Gender Dalam Realitas Sosial, Semarang; UNNES Press.

Burhan Bungin, (2001), Metodologi Penelitian Kualitatif, Jakarta: PT Raja Grafindo Persada.

Cholid Narbuko Dan Abu Ahmadi, (2003), Metode Penelitian, Jakarta: Bumi Aksara. Departemen Agama RI, (2014), Al-quran Terjemahan, Bandung: Diponegoro.

Jalaluddin Rahmat, (1995), Metode Penelitian Komunikasi Dilengkapi Contoh Analisis Statistik, Bandung, Remaja Rosdakarya.

Hasan, Ali, (2003), Masail Fiqhiyah Al-Haditsah Pada Masalah-Masalah Kontemporer Hukum Islam. Jakarta: PT. RajaGrafindo Persada.

Husaini Usman dan Purnomo Setiady Akbar, (2009), Metode Penelitian Sosial, Jakarta: Bumi Aksara.

Farouk Muhammad dan Djali, (2005), Metode Penelitian Sosial, Jakarta: PTIK \& Restu Agung.

Kartini Kartono, (2002), Pengantar Metodologi Research Sosial, Bandung: Alumni.

Lexy J. Maleong, (2007), Metode Penelitian Kualitatif, Bandung: Remaja Rosdakarya.

Muhammad Ali Ash-Shalabi, (2012), Sejarah Lengkap Rasulullah Saw: Fikih dan Study Analisa Komprehensif, Jakarta: Pustaka Al-Kautsar.

Muhammad, Husein, (2001), Fiqh Perempuan Refleksi Kiai Atas Wacana Agama dan Gender, Yogyakarta: LKiS.

M. Zainuri, (2007), Partisipasi Politik Perempuan (Perspektif Tradisi Islam Lokal Kudus), Tesis Universitas Diponegoro, Semarang.

Moh. Nasir, (1988), Metode Penelitian, Jakarta: Ghalia Indonesia.

Masganti Sitorus, (2011), Metodologi Penelitian Pendidikan Islam, Medan: IAIN Press. Mulia, dkk, (2005), Perempuan dan Politik, Jakarta: PT. Gramedia Pustaka Utama Nie'matul Husna, (2010), hak politik perempuan Islam menurut Benazir Bhutto, Tesis UIN Sunan Kalijaga, Yogyakarta.

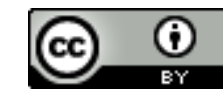

This work is licensed under a Creative Commons Attribution 4.0 International License 


\section{AT-TAIRTR}

VOLUME 13 NOMOR 2 TAHUN 2020

P-ISSN : 1979-9357

E-ISSN : 2620-5858

Sugihartono, dkk, (2007), Psikologi Pendidikan, Yogyakarta:UNY Press. Sugiyona, (2005), Memahami Penelitian Kualitatif, Bandung: Alfabeta.

Winarno Surachman, (1985), Pengantar Penelitian Ilmiah, Bandung: Tarsito.

Walgito, Bimo, (2003), Psikologi Sosial Suatu Pegantar, Yogyakarta: Andi. 